\section{Analisis Kebiasaan Belajar dan Hasil Belajar Biologi Siswa kelas XI IPA SMA Negeri 1 Tinambung}

\author{
Nurul Mujahidah Dainur \\ Mushawwir Taiyeb \\ Muhiddin Pallennari
}

\begin{abstract}
Abstrak. Penelitian ini adalah deskriptif korelasional dengan desain penelitian paradigma sederhana yang bertujuan untuk mengetahui korelasi antara kebiasaan belajar dan hasil belajar siswa. Sampel penelitian ini adalah sampel jenuh yaitu seluruhnya dari populasi kelas XI IPA SMA Negeri 1 Tinambung berjumlah 85 siswa, sampel jenuh bermaksud membuat generalisasi dengan kesalahan yang sangat kecil. Kebiasaan belajar yang diukur meliputi 7 indikator, yaitu teratur belajar Biologi, persiapan belajar pada malam hari, hadir di kelas lebih awal, kondisi/suasana belajar, belajar sampai paham dan tuntas, kebiasaan menghadapi ujian dan kebiasaan mengunjungi perpustakaan. Data penelitian kebiasaan belajar diperoleh melalui angket dan hasil belajar diperoleh dari data sekunder hasil belajar semester genap tahun ajaran 2018/2019 yang kemudian diolah dengan analisis korelasi Product Moment (r) dan koefisien determinasi. Hasil penelitian menunjukkan bahwa (1) Kebiasaan belajar siswa kelas XI IPA SMA Negeri 1 Tinambung pada kategori baik dengan rata-rata 71,98. (2) Hasil belajar biologi siswa kelas XI IPA SMA Negeri 1 Tinambung pada kategori tinggi dengan rata-rata 76,12. (3) Terdapat hubungan antara kebiasaan belajar dengan hasil belajar Biologi siswa kelas XI IPA SMA Negeri 1 Tinambung. Tingkat korelasi yang diperoleh yaitu 11,5\% dan tergolong korelasi lemah atau rendah.
\end{abstract}

Kata Kunci: kebiasaan belajar, hasil belajar.

\section{Pendahuluan}

Tujuan yang ingin dicapai oleh setiap bangsa di dunia yaitu menjadi bangsa yang maju. Maju atau tidaknya suatu negara dipengaruhi oleh faktor-faktor salah satunya yaitu Pendidikan. Berdasarkan Undang-Undang Republik Indonesia tentang Sistem Pendidikian Nasional. Nomor 20 Tahun 2003 Pasal 1, menyatakan bahwa: "Pendidikan adalah usaha sadar dan terencana untuk mewujudkan suasana belajar dan proses pembelajaran agar peserta didik secara aktif mengembangkan potensi dirinya untuk memiliki kekuatan spiritual keagamaan, pengendalian diri, kepribadian, kecerdasan, akhlak mulia, serta keterampilan yang diperlukan dirinya, masyarakat, bangsa dan negara". Seseorang akan mendapatkan ilmu pengetahuan dan keterampilan melalui pendidikan. Ilmu pengetahuan dan keterampilan tersebut dapat mengembangkan potensi seseorang. Bermula dari yang tidak tahu menjadi tahu, dari yang tidak bisa menjadi bisa. Hal ini sesuai dengan prinsip penyelenggaraan pendidikan yang tertuang dalam UndangUndang Republik Indonesia Nomor 20 Tahun 2003 Pasal 4 Ayat 5, menyebutkan bahwa pendidikan diselenggarakan untuk mengembangkan budaya membaca, menulis, dan berhitung bagi setiap warganegara. Keterampilan belajar

\section{Biology Teaching and Learning}

p-ISSN $2621-5527$

e-ISSN 2621 - 5535

Abstract: This research is descriptive correlational with a simple paradigm research design that aims to find out the correlation between study habits and student learning outcomes. The sample of this study is a saturated sample that is entirely from the population of class XI IPA SMA Negeri 1 Tinambung amounting to 85 students, saturated sample intends to make generalizations with very small errors. Measured study habits include 7 indicators, namely regular Biology learning, preparation forlearning in the night, came early to attend the class, conditions / learning

atmosphere, learning to understand and to the point, habit offacing exams and practice of visiting the library. The study data of study habits were obtained through a questionnaire and the learning outcomes were obtained from secondary data on the student achievement of the even semester of the 2018/2019 school year which were

then processed by Product Moment correlation analysis $(r)$ and the coefficient of determination. The results showed that (1) Study habits of students grade XI IPA SMA Negeri 1 Tinambung is at a good category with an average of 71.98. (2) Biology achievement of student grade XI IPA SMA Negeri 1 Tinambung is found out

in high category with an average of 76.12. (3) There is a relationship between the study habits and biology achievement of eleventh grade students at senior high school 1

Tinambung. The correlation level obtained is $11.5 \%$ and classified as weak or low correlation.

Keywords: student habits, student achievements.

Nurul Mujahidah Dainur Universitas Negeri Makassar Indonesia

Mushawwir Taiyeb Universitas Negeri Makassar Indonesia

Muhiddin Pallennari Universitas Negeri Makassar Indonesia 
membaca, menulis, dan berhitung dapat mendorong seseorang untuk mengembangkan bakat dan minatnya. Oleh karena itu, seseorang yang berpendidikan diharapkan dapat menjadi faktor pendorong dalam memajukan suatu bangsa. Namun, dalam proses berjalannya pendidikan itu sendiri tidak lepas dari kegiatan belajar. Belajar merupakan bagian dari dunia pendidikan. Manusia akan melaksanakan kegiatan belajar baik yang disadari maupun tidak. Kegiatan belajar itu dimulai dari awal masa kelahiran hingga sampai akhir hayat manusia.

Dalam proses belajar tersebut seseorang akan mengalami banyak tantangan dan rintangan untuk menjadikannya manusia yang berilmu pengetahuan agar dapat menghadapi kehidupan bersosial dan bermasyarakat. Seseorang akan bertemu dengan orang lain yang tentunya berbeda sifat dan karakter dengannya. Begitupun juga dalam belajar, setiap individu memiliki cara dan karaketristik masing-masing dalam menemukan cara yang membuatnya nyaman dalam belajar sehingga bisa mencapai hasil yang maksimal.

Faktor-faktor yang memengaruhi belajar dapat digolongkan menjadi dua, yaitu faktor yang berasal dari dalam diri peserta didik (faktor internal) dan faktor yang berasal dari luar diri peserta didik (faktor eksternal). Hal ini diuraikan sebagaimana disebutkan oleh Djaali (2015), faktor dari dalam diri diantaranya: kesehatan, Inteligensi, minat dan motivasi, serta cara belajar.

Menurut Syah (2013), mengemukakan bahwa kebiasaan belajar adalah proses pembentukan kebiasaan- kebiasaan baru atau perbaikan kebiasaan yang telah ada. Tujuannya agar peserta didik memperoleh sikap-sikap dan kebiasaan-kebiasaan perbuatan baru yang lebih tepat dan positif dalam arti selaras dengan kebutuhan ruang dan waktu. Pendapat lain dari Aunurrahman (2011), "kebiasaan belajar adalah perilaku belajar seseorang yang telah tertanam dalam waktu yang relatif lama sehingga memberikan ciri dalam aktivitas belajar yang dilakukannya"

Kebiasaan belajar adalah hal-hal atau cara yang dilakukan siswa secara berulang- ulang dalam proses belajarnya yang kemudian hal itu menjadi rutinitas seseorang. Kebiasaan belajar dibentuk sejak awal, sehingga seseorang bisa mengupayakan kebiasaan yang baik untuk memperoleh hasil belajar yang baik. Sedangkan jika menyadari masih ada pengaruh yang bisa membawa dampak negative bagi kebiasaan belajarnya maka perlu upaya untuk meninggalkan kebiasaan tersebut.

Menurut Sudjana (2005), kebiasaan belajar teratur dimulai dari cara mengikuti pelajaran, cara belajar mandiri, cara belajar kelompok, cara mempelajari buku pelajaran, dan cara menghadapi ujian. Sedangkan Menurut Bakare (1970), indikator kebiasaan belajar meliputi: tugas dan pekerjaan rumah, alokasi waktu untuk belajar, Membaca dan pencatatan, Periode masa belajar/persiapan tes, dan pengambilan tes (ujian).

Kebiasaan belajar sangat penting diketahui oleh setiap individu, sehingga jika menyadari kebiasaan belajar yang dilakukan selama ini kurang baik dibutuhkan upaya untuk mengetahui kebiasaan belajar yang seperti apa yang baik untuk meningkatkan hasil belajarnya. Sedangkan jika kebiasaan belajar siswa sudah cukup baik, maka perlu dipertahankan atau lebih baiknya ditingkatkan lagi.

Kebiasaan belajar merupakan salah satu kunci dalam mencapai hasil belajar. Vipene (2005) berpendapat bahwa kebiasaan belajar yang baik adalah aset kepada yang para pelajar. Karena kebiasaan belajar membantu siswa untuk mencapai nilai atau performa yang baik. Sebaliknya, ketika ada Batasan atau paksaan dalam belajar akan menghambat pembelajaran dan hasil belajar siswa hingga kegagalan akademik. Capaian atau hasil dari sebuah kebiasaan belajar yang baik adalah membentuk kepercayaan diri siswa, persiapan yang baik sebelum, selam dan setelah ujian. Kebiasaan belajar yang baik membantu pelajar untuk memperoleh keterampilan atau keahlian yang lebih baik untuk prestasi akademik yang efektif. 


\section{Metode Penelitian}

Penelitian ini merupakan descriptive correlational yang bertujuan untuk mengetahui hubungan antara kebiasaan belajar dan hasil belajar Biologi siswa kelas XI IPA SMA Negeri 1 Tinambung. Adapun desain penelitian ini ialah simple paradigm research design.

Penelitian ini dilaksanakan di SMA Negeri 1 Tinambung pada bulan Juli hingga Agustus 2019. Populasi dalam penelitian ini adalah seluruh siswa kelas XI IPA SMA Negeri 1 Tinambung yang terdaftar pada tahun ajaran 2018/2019 berjumlah 85 orang, sedangkan pengambilan sampel dilakukan secara sampling jenuh dengan maksud membuat generalisasi dengan kesalahan yang sangat kecil maka yang akan dijadikan sampel dalam penelitian ini adalah seluruh dari populasi, yaitu seluruh siswa kelas XI IPA SMA Negeri 1 Tinambung yang terbagi dalam 3 kelas. Kelas XI IPA 1 berjumlah 28 siswa, Kelas XI IPA 2 berjumlah 29 siswa, dan Kelas XI IPA 3 berjumlah 28 siswa. Jadi jumlah sampel penelitian seluruhnya 85 siswa.

Teknik pengumpulan data yang digunakan dalam penelitian ini adalah (1) Tes dengan menggunakan angket untuk menilai kebiasaan belajar siswa sesuai indikator kebiasaan belajar (2) hasil belajar diperoleh dari data sekunder sekolah yaitu nilai ujian akhir semester genap tahun ajaran 2018/2019. Teknik analisis data yang digunakan yaitu analisis statistik deskripstif dan statistik inferensial dengan menggunakan uji korelasi "Product Moment".

\section{Hasil Penelitian}

Analisis Statistik Deskriptif Kebiasaan Belajar

Tabel 1. Persentase dan Kategori Kebiasaan Belajar Siswa Kelas XI IPA SMA Negeri 1 Tinambung

\begin{tabular}{|c|c|c|c|c|}
\hline No. & Rentang nilai & Siswa & Persentase (\%) & Kategori \\
\hline 1 & $85-112$ & 28 & 32,94 & Sangat baik \\
\hline 2 & $70-84$ & 53 & 62,35 & Baik \\
\hline 3 & $56-69$ & 4 & 4,70 & Cukup \\
\hline 4 & $<55$ & 0 & 0 & Kurang \\
\hline & 85 & \multicolumn{4}{|l}{} \\
\hline
\end{tabular}

Nilai rata-rata tabel yang didapat dari hasil data angket kebiasaan belajar siswa adalah 71,98 dan berdasarkan kategori pengklasifikasian nilai rata-rata angket kebiasaan belajar siswa berada pada rentang antara 70-84 maka rata-rata tingkat kebiasaan belajar siswa kelas XI IPA SMA Negeri 1 Tinambung dapat dikategorikan baik.

Tabel 2. Distribusi Persentase Jawaban Angket Kebiasaan Belajar Siswa untuk Tiap Indikator

\begin{tabular}{|c|l|c|c|c|c|}
\hline No. & \multicolumn{1}{|c|}{ Indikator } & \multicolumn{2}{c|}{ Persentase } & \\
\hline & & SS & S & TS & STS \\
\hline 1 & Belajar Biologi secara teratur & $13,5 \%$ & $40 \%$ & $44,7 \%$ & $1,5 \%$ \\
\hline 2 & $\begin{array}{l}\text { Mempersiapkan keperluan belajar pada } \\
\text { malam hari }\end{array}$ & $30,6 \%$ & $45 \%$ & $21,1 \%$ & $2 \%$ \\
\hline 3 & Kebiasaan hadir di kelas lebih awal & $42,7 \%$ & $44,1 \%$ & $11,5 \%$ & $0,6 \%$ \\
\hline 4 & Suasana ketika belajar & $13,8 \%$ & $45,9 \%$ & $35,3 \%$ & $4,4 \%$ \\
\hline 5 & $\begin{array}{l}\text { Kebiasaan belajar sampai paham dan } \\
\text { tuntas }\end{array}$ & $31,7 \%$ & $60,3 \%$ & $7,9 \%$ & $0 \%$ \\
\hline 6 & Kebiasaan menghadapi ujian & $32 \%$ & $56 \%$ & $10,6 \%$ & $1,2 \%$ \\
\hline 7 & Kebiasaan mengunjungi perpustakaan & $10,2 \%$ & $45,9 \%$ & $40,8 \%$ & $2,7 \%$ \\
\hline
\end{tabular}


Berdasarkan Tabel 2 dapat disimpulkan bahwa untuk memperoleh persentase kategori baik untuk setiap indikator dengan cara menjumlahkan persentase jawaban sangat setuju dengan jawaban setuju sehingga diperoleh sebanyak 53,5\% siswa belajar Biologi secara teratur. Kemudian ada $75,6 \%$ siswa mempersiapkan pembelajaran pada malam hari. Pada indikator ketiga, ada $82,8 \%$ siswa hadir di kelas lebih awal sebelum pelajaran dimulai. Pada indikator keempat, ada 59,7\% siswa yang masih kurang baik kebiasaan belajarnya dalam pertimbangan kondisi saat belajar. Pada indikator kelima, ada 92\% siswa yang mengupayakan diri untuk belajar sampai pahan dan tuntas. Pada indikator keenam, ada $88 \%$ siswa yang sudah mempersiapkan diri menghadapi ujian. Dan untuk indikator terakhir, sebanyak $56,1 \%$ siswa yang masih sering mengunjungi perpustakaan sekolah baik untuk mengerjakan tugas atau memanfaatkan waktu saat jam pelajaran kosong.

\section{Analisis Statistik Inferensial Hasil Belajar}

Tabel 3. Kategori Hasil Belajar Siswa Kelas XI IPA SMA Negeri 1 Tinambung

\begin{tabular}{|c|c|c|c|c|}
\hline No. & Rentang nilai & Siswa & Persentase (\%) & Kategori \\
\hline 1 & $86-100$ & 4 & 4,70 & Sangat tinggi \\
\hline 2 & $70-85$ & 81 & 95,30 & Tinggi \\
\hline 3 & $50-69$ & 0 & 0 & Cukup \\
\hline 4 & $<49$ & 0 & 0 & Kurang \\
\hline & 85 & \multicolumn{4}{l}{} \\
\hline
\end{tabular}

Nilai rata-rata tabel yang didapat dari data hasil belajar siswa adalah 76,12 dan berdasarkan kategori pengklasifikasian di atas nilai rata-rata hasil belajar siswa berada pada rentang antara 70-85 maka rata-rata tingkat hasil belajar siswa kelas XI IPA SMA Negeri 1 Tinambung dapat dikategorikan tinggi.

\section{Hasil Analisis Statistik Inferensial}

Hasil perhitungan antara dua variabel akan diuji keabsahannya dengan menggunakan rumus Product Moment sehingga diperoleh tingkat korelasi antara kebiasaan belajar dan hasil belajar siswa yaitu: $r x y=0,3396$ dan terletak antara $0,20-0,40$ yang berarti korelasi antara variabel $\mathrm{X}$ dan $\mathrm{Y}$ terdapat korelasi yang lemah atau rendah.

Setelah mendapatkan rhitung sebesar 0,3396 selanjutnya dikonsultasikan dengan tabel $r$ Product Moment. Pada tabel diketahui untuk nilai $\mathrm{df}=\mathrm{N}-\mathrm{nr}$, yaitu $\mathrm{df}=85-2=83$, dengan " $\mathrm{df}$ " sebesar 83 dikonsultasikan dengan tabel nilai "r", ternyata pada taraf signifikan $(\alpha)=0,05$ diperoleh nilai rtabel sebesar 0,1796. rhitung > rtabel $(0,3396>0,1796)$. Ini berarti ada hubungan yang signifikan antara kebiasaan belajar yang dimiliki siswa dengan prestasi belajar siswa kelas XI IPA SMA Negeri 1 Tinambung.

Untuk mengetahui seberapa besar kontribusi atau sumbangan yang diberikan oleh variabel $\mathrm{X}$ terhadap variabel $\mathrm{Y}$ maka harus diketahui terlebih dahulu suatu koefisien yang disebut Coefisien of Determination atau koefisien penentuan dengan rumus $\mathrm{Kd}=\mathrm{r}^{2} \times 100 \%$ sehingga diperoleh $\mathrm{Kd}$ sebesar 11,5\%. Hal ini menunjukkan bahwa variabel X (Kebiasaan belajar) memberikan kontribusi kepada variabel Y (Hasil Belajar) sebesar 11,5\%.

Uji hipotesis dilakukan untuk melihat ada tidaknya hubungan antara kebiasaan dan hasil belajar Biologi siswa kelas XI IPA SMA Negeri 1 Tinambung. Kriteria pengujian hipotesis dalam bentuk statistik dirumuskan dengan: H0: $\rho=0$ (tidak ada hubungan) dan Ha: $\rho \neq 0$ (ada hubungan).

Berdasarkan pada data yang diperoleh dari hasil analisis korelasi product moment diperoleh rhitung sebesar 0,3396 dan nilai dari rtabel pada taraf signifikan $(\alpha)=0,05$ sebesar 0,1796 . Nilai rhitung $>$ rtabel atau $\rho \neq 0$ maka Ha diterima dan $\mathrm{H} 0$ ditolak yang berarti bahwa 
ada hubungan antara kebiasaan belajar dengan hasil belajar Biologi siswa kelas XI IPA SMA 1 Tinambung.

\section{Pembahasan}

\section{Kebiasaan belajar dan Hasil belajar}

a. Kebiasaan belajar Biologi secara teratur

Pada data hasil penelitian menunjukkan bahwa ada 53\% siswa yang memiliki keteraturan dalam belajar Biologi. Pendapat Crow dan Alice (2007) kebiasaan belajar yang efektif meliputi rencana atau tempat, penentuan waktu yang pasti dan membuat catatan singkat yang terorganisir dengan baik. Hal tersebut sesuai dengan pendapat dari Kartadinata dan Yusuf (1999) yang menyatakan bahwa kebiasaan belajar merupakan pola perilaku belajar siswa ketika berada di rumah dan di sekolah yang dilakukan secara terus-menerus. Gie (1995) menambahkan sikap disiplin akan menciptakan keluwesan untuk belajar secara teratur, dan membuat pelajar memiliki cara belajar yang baik,

b. Kebiasaan mempersiapkan keperluan belajar pada malam hari

Data hasil penelitian menunjukkan ada $75 \%$ mempersiapkan pembelajaran pada malam hari. Aunurrahman (2011) berpendapat kebiasaan belajar yang baik dapat dilihat dari kesediaan siswa dalam mencatat pelajaran, mempersiapkan buku serta alat-alat pelajaran yang diperlukan. Pendapat tersebut Didukung oleh Gie (1995) yang menegmukakan bahwa peralatan belajar harus dimiliki seorang pelajar agar dia lebih berkonsentrasi engan yang dipelajari. Menurut Sudjana (2005) Persiapan belajar yang perlu dilakukan adalah berupa mempelajari materi yang akan dibahas, dan mengulang lagi materi yang sudah dipelajari sebelumnya

c. Kebiasaan hadir di kelas lebih awal

Indikator ketiga menunjukkan ada 80\% siswa hadir di kelas lebih awal dan tertib dalam mengikuti pembelajaran di sekolah. Selain persiapan peralatan belajar, penting juga untuk menyiapkan mental siswa. Hal ini sejalan dengan pendapat Wood (2000), percaya bahwa yang paling penting dari semua bahan untuk sesibelajar yang efektif adalah kesiapan mental siswa untuk memulai pelajaran. Seorang siswa yang disiplin dalam adopsi dan pemanfaatan kebiasaan belajarnya memiliki peluang lebih tinggi untuk maju dalam bidang pengetahuan.

d. Kondisi/suasana ketika belajar

Pada indikator keempat menunjukkan ada 60\% siswa yang masih kurang baik kebiasaan belajarnya dalam pertimbangan kondisi saat belajar. Pendapat O'Hara (2005) yang mengemukakan bahwa Kebiasaan belajar yang baik juga melibatkan menghindari gangguan. Area belajar siswa harus dibersihkan dari segala macam gangguan seperti TV dan sistem permainan. Dianjurkan untuk menempatkan area studi jauh dari area hiburan atau untuk memastikan bahwa semua mode hiburan dimatikan. Djaali (2015) menambahkan kebiasaan belajar seseorang termasuk juga pada usaha untuk menghindarkan diri dari hal-hal yang memungkinkan tertundanya penyelesaian tugas dan menghilangkan rangsangan yang akan mengganggu konsentrasi belajar.

e. Kebiasaan belajar sampai paham dan tuntas

Indikator kelima juga menunjukkan ada 90\% siswa mengupayakan diri untuk belajar sampai pahan dan tuntas. Hal ini berkaitan dengan pemanfaatan sumber belajar yang variatif (bisa dari media cetak dan media elektronik yang sekarang ini makin berkembang) dan memanfaatkan hubungan dengan teman dan guru dalam upaya menanyakan hal atau materi yang belum dimengerti kepada mereka. Hal tersebut sesuai dengan pendapat dari Gie (1995) yang menyatakan bahwa salah satu bentuk kebiasaan belajar yang baik yaitu terbiasa belajar sampai paham betul dan bahkan tuntas tanpa terlupakan lagi. Sedangkan menurut Sudjana (2005) hal yang dilakuakan ketika belum memhami materi tertentu yakni membuat pertanyaan- pertanyaan dari materi yang belum dipahami dan menanyakannya 
kepada teman atau guru yang bersangkutan.

f. Kebiasaan menghadapi ujian

Pada indikator keenam juga menunjukkan ada 88\% siswa yang mempersiapkan diri menghadapi ujian. Hal ini menyangkut kedisiplinan siswa dalam belajar. Sudjana (2005) mengemukakan bahwa Sebelum menghadapi ujian, siswa perlu mempersiapakan mental, fisik dan materi ujian. Persiapan mental dilakukan dengan memperbanyak doa dan beribadah. Lalu persiapan fisik berupa tidur teratur, tidak begadang semalaman untuk belajar dan makan makanan yang sehat. Hal terpenting yang perlu dilakukan adalah, memperlajari kembali materi yang akan diujikan. Ketika ujian berlangsung, sebaiknya siswa datang tepat waktu, membaca soal dengan teliti, mengerjakan soal dari yang mudah ke soal yang sulit, dan yang terakhir adalah memeriksa kembali jawaban yang dipilih.

g. Kebiasaan mengunjungi perpustakaan

Dan indikator terakhir menunjukan ada 56\% siswa yang masih sering mengunjungi perpustakaan sekolah baik untuk mengerjakan tugas atau memanfaatkan waktu saat jam pelajaran kosong. Seorang siswa harus memiliki lingkungan belajar yang baik. Perpustakaan adalah tentang tempat belajar terbaik. Hal itu sejalan dengan pendapat Akinboye (1980) menggambarkan perpustakaan sebagai pusat kekuatan akademik dan hubungan utama antara siswa dan kebijaksanaan zaman. Aanu dan Olatoye (2011) meneliti pengaruh gabungan dan relatif penggunaan sumber daya perpustakaan dan kebiasaan belajar pada prestasi sains siswa sekolah menengah pertama di Ogun State, Nigeria. Mereka menemukan bahwa penggunaan sumber daya perpustakaan dan kebiasaan belajar digabungkan bersama untuk secara signifikan mempengaruhi pencapaian hasil belajar siswa.

\section{Hubungan antara kebiasaan belajar dan hasil belajar}

Dari data hasil penelitian diperoleh bahwa beberapa siswa yang meiliki hasil belajar berkategori tinggi (dengan hasil belajar di atas 80) juga memiliki kebiasaan belajar yang berkategori sangat baik. Perolehan perhitungan korelasional antara kebiasaan belajar dengan hasil belajar siswa yaitu sebesar 0,3396 dan setelah dikonsultasikan pada table nilai " $r$ " Product Moment berada diposisi 0,20 - 0,40 yang berarti antara kebiasaan belajar dan hasil belajar terdapat korelasi yang rendah atau lemah. Begitu juga dengan hasil peritungan koefisien determinasi atau kontribusi kebiasaan belajar terhadap hasil belajar adalah sebesar $11,5 \%$. Hal ini menunjukkan bahwa kebiasaan belajar merupakan salah satu faktor yang mempengaruhi hasil belajar siswa. Hasil pengujian hipotesis dengan mengguanakan uji hipotesis korelasi diperoleh nilai rhitung sebesar 0,3396 dan rtabel pada taraf kepercayaan 0,05 sebesar 0,1796. Ini menunujukkan bahwa nilai rhitung > rtabel yang berarti hipotesis yang daijukan diterima. Dengan demikian, dapat disimpulkan bahwa terdapat hubungan antara kebiasaan belajar dengan hasil belajar siswa kelas XI IPA SMA Negeri 1 Tinambung.

Kontribusi kebiasaan belajar sebesar 11,5\% dan 88,5\% dipengaruhi oleh variable lain di luar penelitian. Hasil uji hipotesis ini sejalan dengan penelitian yang dilakukan Zakiyah (2016; 109) yang memperoleh kontribusi kebiasaan belajar terhadap dan hasil belajar siswa kelas IV SD Kecamatan Kaliwungu sebesar 31\% dan sisanya 69\% dipengaruhi oleh variable lain. Faktor lain yang mempengaruhi hasil belajar menurut Djaali (2015) yaitu kesehatan, Inteligensi, serta minat dan motivasi.

Penyebab rendahnya korelasi antara kebiasaan belajar dengan hasil belajar siswa kelas XI IPA SMA Negeri 1 Tinambung sebesar 11,5\% yaitu peneliti tidak bisa menjamin bahwa siswa benar-benar menjawab semua pernyataan pada angket sesuai dengan kepribadiannya. Selain itu menurut Cerna dan Pavlinshchenko (2015) banyak hal yang dapat mempengaruhi kebiasaan belajar siswa diantaranya; usia, lingkungan tempat tinggal siswa, kegiatan non akademik siswa, tekad dan kesadaran siswa untuk belajar. Jadi meskipun kebiasaan belajar yang baik bisa 
dibentuk seiring dengan berjalannya waktu, hal itu tidak akan terwujud tanpa tekad dan kesadaran dari siswa sendiri untuk mengupayakan perubahan dalam kebiasaan belajar mereka yang kurang baik. Perhatian orang tua juga sangat berpengaruh terhadap keberhasilan siswa dalam belajar, karena bukan hanya tugas guru saja untuk mengarahkan siswa dalam kegiatan akademiknya.

\section{Kesimpulan}

Kesimpulan yang diperoleh dari penelitian ini adalah, kebiasaan belajar siswa kelas XI IPA SMA Negeri 1 Tinambung menunjukkan 62,35\% siswa pada kategori baik. Hasil belajar biologi siswa kelas XI IPA SMA Negeri 1 Tinambung menunjukkan 95,30\% siswa pada kategori tinggi. Terdapat hubungan antara tingkat kebiasaan belajar siswa terhadap hasil belajar Biologi siswa kelas XI IPA SMA Negeri 1 Tinambung. Tingkat korelasi yang diperoleh yaitu 11,5\% dan tergolong korelasi lemah atau rendah.

\section{Referensi}

Aanu, E. M. \& Olatoye, R. A. (2011). Use of Library Resources, Study Habits and Science Achievement of Junior Secondary School Students. Journal of Educational Research. 2 (7), 1265-1269.

Akinboye, J.O. (1980). A Study of Self- Concept Study Behaviour and Health Attributes of Male and Female Nigerian Adolescents. Journal of African Child Studies. 1 (2), 21-27.

Aunurrahman. (2011). Belajar dan Pembelajaran. Alfabeta. Bandung.

Bakare, C. G. M. (1970). Study Habits Inventory. Nigeria. Department of Guidiance and Counselling, University of Ibadan.

Crede, M. \& Kuncel, N. R. (2008). Study Habit, Skills and Attitude:the Third Pillar Supporting Collegiate Academic Performances. Perspective on Psychological Science. 25, 147-166.

Cerna, M. A. \& Pavlinshchenko, K. 2015. Influence of Study Habits on Academic Performance of International College Students in Shangai. Higher Education Studies, 5 (4), 42-45.

Crow, L. D. \& Alice, D. C. (2007). Psikologi Pendidikan. (Terjemahan oleh Meitasari Tjandrasa). Surabaya. PT. Bina Ilmu.

Djaali. (2015). Psikologi Penddikan. Jakarta. Bumi Aksara.

Gie, T. L. (1995). Cara Belajar yang Efisien. Yogyakarta: Pusat Kemajuan Study. Kartadinata, S. \& Yusuf, S. (1999). Bimbingan di Sekolah Dasar. Bandung: Depatemen Pendidikan dan Kebudayaan Direktorat Jenderal Pendidikan Tinggi.

Mappease, Y. (2009). Pengaruh Cara dan Motivasi Belajar Terhadap Hasil Belajar Programmable Logic Controller (PLC) Peserta Didik Kelas III Jurusan Listrik SMK Negeri 5 Makassar. Jurnal Medtek, 1 (2).

O’Hara, S. (2005). Improving your Study Skills, New Jersey. Wiley publishing, Inc.

Sudjana, N. (2005). Penilaian Hasil Proses Belajar Mengajar. Bandung: Remaja Rosdakarya. 
Vipene, J. B. (2005). Introduction to Psychological Foundation of Education. Port Harcourt. Harey Publications.

Wood, G. (2000). How to study, use your personal learning style to help (second ed.) New York: Learning Express, LLC.

Zakiyah, A. F. (2016). Hubungan antara Kebiasaan Belajar dan Hasil Belajar Siswa Kelas IV SD Gugus Muwardi Kecamatan Kaliwungu. Skripsi. Semarang. Universitas Negeri Semaran.

\begin{tabular}{|l|l|}
\hline $\begin{array}{l}\text { Nurul Mujahidah } \\
\text { Dainur }\end{array}$ & $\begin{array}{l}\text { Mahasiswa Jurusan Biologi, FMIPA, Universitas Negeri } \\
\text { Makassar } \\
\text { Email: nurulmujahidahdainur@gmail.com }\end{array}$ \\
\hline Mushawwir Taiyeb & $\begin{array}{l}\text { Dosen Jurusan Biologi, FMIPA, Universitas Negeri } \\
\text { Makassar } \\
\text { Email: mtaiyeb333@gmail.com }\end{array}$ \\
\hline Muhiddin Pallennari & $\begin{array}{l}\text { Dosen Jurusan Biologi, FMIPA, Universitas Negeri } \\
\text { Makassar } \\
\text { Email: muhiddin.p@unm.ac.id }\end{array}$ \\
\hline
\end{tabular}

